\title{
Obesity and Cancer: Evidence, Postulated Mechanisms and Prospectives
}

\author{
Hala Fawzy Mohamed Kamel ${ }^{1,2^{*}}$, Hiba Saeed A Bagader Al-Amodi ${ }^{1}$ and Mohammed Hasan \\ Mukhtar $^{1}$ \\ ${ }^{1}$ Biochemistry Department, Faculty of Medicine Umm AL-Qura University, Makhha 21955, Saudi Arabia \\ ${ }^{2}$ Medical Biochemistry Department, Faculty of Medicine, Ain Shams University, Cairo 11566, Egypt
}

Received: : December 24, 2016; Accepted: February 20, 2017; Published:April 04, 2017

*Corresponding author: Hala Fawzy Mohamed Kamel, Assistant Professor, Faculty of Medicine Umm AL-Qura University, Al-Abdeyah campus, Ring Road 4, Makhha 21955, Saudi Arabia, Tel: +9665 0356 2841; Fax: +9661 2527 0000- 4318; E-mail: kamelhala@msn.com, dr.halakamel@gmail.com

\begin{abstract}
Obesity is a major health problem tremendously increasing worldwide, obesity has been accompanied by a state of metabolic dysregulation, characterized by insulin resistance and may be associated with many comorbidities such as metabolic syndrome, type 2 diabetes and cardiovascular complications. Lately a great attention has been gained toward the association of obesity with certain cancers. Numerous studies and meta-analysis reported that, obesity is associated with increased risk of esophageal adenocarcinoma, postmenopausal breast cancer, and endometrial, renal, pancreatic, prostate and colorectal cancers. In spite of, the evidence of such association that link obesity with risk and recurrence or death from cancer, however the linking mechanisms has not been yet fully explained. Obesity may promote cancer by: 1) alteration of adipocytokines: Leptin, adiponectin, resistin and visfatin with promotion of angiogenesis and interactions with other mediators and cytokines. 2) Hypoxia and angiogenesis due to expansion of adipose tissue with release of certain mediators that stimulate angiogenesis. 3) Metaflammation state of low grade and chronic inflammation that merely stimulate release of cytokines as (TNF $\alpha$ ) and (IL-6) and the activation of pro-inflammatory signaling. 4) Insulin resistance with hyperinsulinemia and increased levels of insulin and growth factors as IGFs and IGF binding proteins. 5) Increased levels of sex steroids, including estradiol and Dehydroepiandrosterone (DHEA) particularly in cases of endometrial and postmenopausal breast cancers. 6) oxidative stress and reduction of antioxidants with possibility of oxidative damage or mutation of DNA. 7) epigenetic mechanisms, including DNA methylation, histones and chromatin remodeling factors . In fact, it remains unclear how the convergence of these mechanisms may drive obesity-associated cancer, considering the complex and multi-factorial characterization of cancer as well as the variation of genetics background of obese subjects. Prospective studies is worth pursuing especially towards therapeutic implications to prevent or treat obesity- associated cancer. Our aim is providing updated and comprehensive review about postulated and prospective links and molecular mechanisms between obesity and cancer, focusing upon mechanistic mediators that may drive obesity- associated cancers and may be targeted molecules for prospectives therapies
\end{abstract}

Key words: Cancer; Obesity; Adipokines; Insulin resistance; Proteomics

\section{Introduction}

The pandemic of obesity is alarming and expanding all over the world [1]. It was estimated that, 2.2 billion adults are overweight or obese worldwide. Moreover, estimations based on regression analysis, suggested that , by 2030 ,more than $20 \%$ of adults will be obese in addition to $38 \%$ will be overweight as well, if the current trends continue in the same manner[2,3]. Obesity as a chronic disease, is strongly associated with an increase in mortality and morbidity. Obesity is merely linked to metabolic dysregulations as insulin resistance, and associated with comorbidities as diabetes mellitus type 2, hypertension, cardiovascular complications and certain types of cancers [4]. Many reports has focused on the association of obesity with some types of cancers as adenocarcinoma of the esophagus, post-menopausal breast, ovarian, endometrium, liver, colorectal, gallbladder, pancreas, kidney, gastric cardia, as well as nonHodgkin lymphoma, multiple myeloma, metastatic prostate cancer, and unfortunately the list of cancer types is increasing [5-11]. Even more, obesity has been linked to increase the risk of recurrence, and deaths among cancer patients, thereby, better exploration and comprehensive understanding of the linking mechanisms between obesity and occurrence or aggressiveness of certain cancers, will allow the development of recent strategies against cancer [12-14]. While obesity is associated with an increased risk of several malignancies, other types of cancer as squamous cell carcinoma of esophagus, lung and premenopausal breast cancer may exhibit inverse association with obesity [15-17]. The concept of association of metabolic dysregulation encountered in obesity and carcinogenesis was firstly enunciated by Otto Warburg [18]. Fifty years later, the International Agency for Research on Cancer (IARC) reported that, avoiding weight gain could be protective against some cancers [19]. Substantial observational studies and supporting evidences has suggested the positive association between obesity with risk increase of many cancers, and with increased risk of cancer mortality $[20,21]$. Indeed, such associations were well established by 
several epidemiological and large prospective studies; however, the linking mechanism has not been fully understood. Previously, IARC, American Institute for Cancer Research ( AICR) and World Cancer Research Fund (WCRF) reported the convincing evidence for the association of obesity with certain types such as, endometrial, esophageal adenocarcinoma, colorectal, postmenopausal breast, prostate, and renal carcinoma [1,2125]. To Lesser extent, other malignancies may be associated with obesity as malignant melanoma, thyroid cancers, leukemia, nonHodgkin's lymphoma, and multiple myeloma [26,27]. Other few studies have investigated the association of obesity with stomach and cervical cancer but less data and evidences were reported $[28,29]$. Other reports suggested a probable evidence for association of obesity with gallbladder cancer and aggressiveness of prostate cancer [30].Types of cancers that has been linked to obesity with their associated findings are summarized in Table 1. In this review, we will focus upon the proposed linking mechanisms and suggested mediators of obesity-associated cancers.

\section{Mechanisms linking obesity with cancer}

It was estimated that about $20 \%$ of all cancers may be influenced by obesity and approximately the half of cancer cases can be attributed to obesity in postmenopausal women [54], additionally substantial recent evidences has supported the cause-and-effect relationship in-between obesity or overweight at one side and the onset of these cancers on the other side [34]. Association and influence of obesity and cancer risk is merely gender and type of cancer specific, however the higher risk for different types of cancer is pivotally due to life style, dietary factors and anthropometric parameters as BMI or waist circumference, these factors activate several molecular or biological mechanisms [55]. It seems likely that obesity attributes to cancer through many mechanisms and various mechanisms could work differently in different people; substantially the etiology of cancers is different in different types and sites of cancer. For example, insulin and growth factors may drive prostate and colon cancer [56], whereas sex steroids may drive breast and

Table 1: Types and evidences for association of obesity and cancer

\begin{tabular}{|c|c|c|}
\hline Type of cancer & Findings for association of obesity with cancer & References \\
\hline \multirow[t]{3}{*}{$\begin{array}{l}\text { Post-menopausal breast } \\
\text { cancer }\end{array}$} & $\begin{array}{l}\text { Obesity increases breast cancer risk by } 50 \% \text {, in postmenopausal women with } \\
\text { increased serum concentrations of free estradiol }\end{array}$ & {$[31,32]$} \\
\hline & $\begin{array}{l}\text { Obesity increases breast cancer risk among non-hormone replacement } \\
\text { therapy users of postmenopausal women }\end{array}$ & [33] \\
\hline & $\begin{array}{l}\text { For increasing BMI by } 5 \mathrm{~kg} / \mathrm{m} 2 \text {, the risk of postmenopausal breast cancer by } \\
31 \%\end{array}$ & {$[34]$} \\
\hline \multirow[t]{2}{*}{ Colorectal cancer } & Obesity is related to a higher risk of colorectal cancer & {$[22,35]$} \\
\hline & $\begin{array}{l}\text { waist circumference and the waist/hip ratio are also strongly associated with } \\
\text { colorectal cancer }\end{array}$ & [36] \\
\hline \multirow[t]{2}{*}{$\begin{array}{l}\text { Esophageal } \\
\text { adenocarcinoma }\end{array}$} & $\begin{array}{l}\text { Obesity is associated with a } 3 \text {-fold increase in risk for adenocarcinoma of the } \\
\text { esophagus }\end{array}$ & {$[24,37,38]$} \\
\hline & $\begin{array}{l}\text { High BMI is associated with gastroesophageal reflux } \\
\text { is very strongly associated with esophageal adenocarcinoma }\end{array}$ & [39] \\
\hline \multirow[t]{2}{*}{ Endometrial cancer } & $\begin{array}{l}\text { Obesity is associated with } 2 \text { to } 3 \text {-fold increase in risk for developing } \\
\text { endometrial in obese women than in lean women }\end{array}$ & {$[21,40]$} \\
\hline & $\begin{array}{l}40 \% \text { of endometrial cancer incidence has been estimated to be attributable to } \\
\text { excess body weight }\end{array}$ & {$[22]$} \\
\hline \multirow[t]{2}{*}{$\begin{array}{l}\text { Hepatocellular } \\
\text { carcinoma (HCC) }\end{array}$} & $\begin{array}{l}\text { the relative risk of mortality from liver cancer was } 1.68 \text { times higher in obese } \\
\text { women and } 4.52 \text { times higher in obese men }\end{array}$ & {$[21]$} \\
\hline & Obesity is a risk factor for the development of HCC & {$[41,42]$} \\
\hline \multirow[t]{2}{*}{ Prostate cancer } & $\begin{array}{l}\text { Obesity significant positive association with an estimated increase in prostate } \\
\text { cancer risk ( } 5 \% \text { excess risk per } 5 \text { unit increment of BMI) }\end{array}$ & {$[43,44]$} \\
\hline & $\begin{array}{l}\text { high BMI at time of prostate cancer diagnosis was } \\
\text { associated with increased overall mortality }\end{array}$ & [45-47] \\
\hline \multirow[t]{2}{*}{ Pancreatic cancer } & $\begin{array}{l}\text { High BMI is associated with doubling of risk for pancreatic cancer in men and } \\
\text { women }\end{array}$ & {$[24]$} \\
\hline & $\begin{array}{l}\text { Positive association of Pancreatic cancer with waist circumference in men not } \\
\text { in women }\end{array}$ & [48] \\
\hline \multirow[t]{2}{*}{ Renal cell carcinoma } & Obesity is associated with high risk for renal cell carcinoma & {$[23,49]$} \\
\hline & $\begin{array}{l}\text { Obesity has inverse relationship with prognosis in renal cell carcinoma, } \\
\text { associated with post-operative complications. }\end{array}$ & [50-52] \\
\hline Ovarian cancer & $\begin{array}{l}\text { Obesity may affect survival by negative impact on surgical and } \\
\text { chemotherapeutic intervention }\end{array}$ & [53] \\
\hline
\end{tabular}


endometrial cancer. On the other hand, chronic inflammation may drive other types of cancers, in fact all of the previous mechanisms may contribute to carcinogenic effect of obesity in site specific or in universal and direct way [57]. Universally acting mechanisms could promote carcinogenesis for all or majority of malignancies, simply because those mechanisms are consequences of hormonal and metabolic alterations prevalent in obesity. Otherwise, site-specific mechanisms could particularly promote tumors whenever complications of obesity heightens the risk for one type of cancer at specific site as for example risk of adenocarcinoma of esophagus as an assumed effect of aggravated gastro-esophageal reflux or for liver cancer can be a consequence of nonalcoholic steatohepatitis being comorbid effects of obesity [58]. Obesity occurs when caloric intake exceeds energy expenditure causing excess accumulation of adipose tissue. White Adipose Tissue (WAT) has been considered as an endocrine organ beside its main primary role as a fuel reservoir organ. WAT secretes adipokines, sex steroids, and cytokines that, are involved in regulation of fuel storage, metabolism, food intake, insulin sensitivity, and immunological function [59]. Most of the obesity linked diseases or morbidity changes, such as diabetes mellitus, insulin resistance, coronary heart diseases and cancers are mostly caused by alteration or dysfunction of WAT leading to a state of chronic inflammation with alteration of excretion of adipokines and cytokines [60]. Adipokines, cytokines secreted from adipose tissue together with the state of low grade inflammation (Metaflammation) and expanded hypoxic adipose tissue are among the proposed mechanisms that may promote carcinogenesis in obese subjects. Proposed linking mechanisms of obesity and cancer are illustrated in Figure 1; linking mediators are summarized in Figure 2.

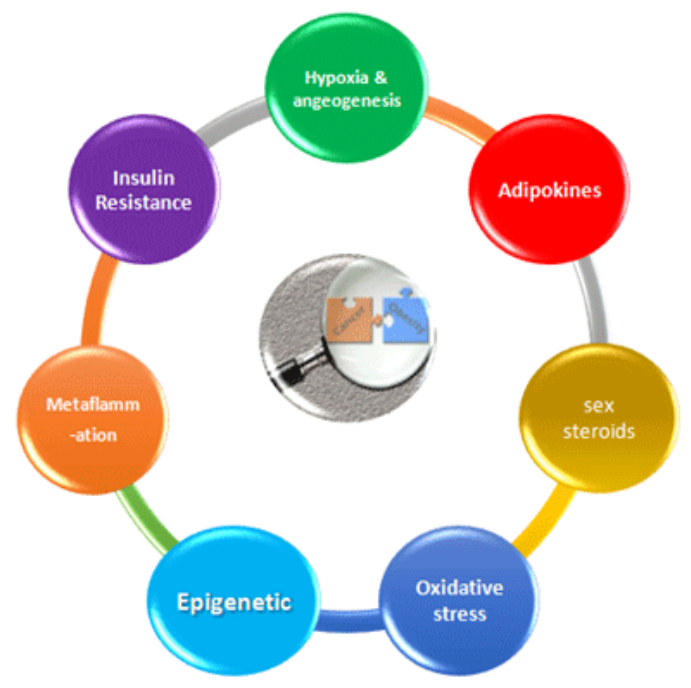

Figure 1: Mechanisms linking Obesity with Cancer

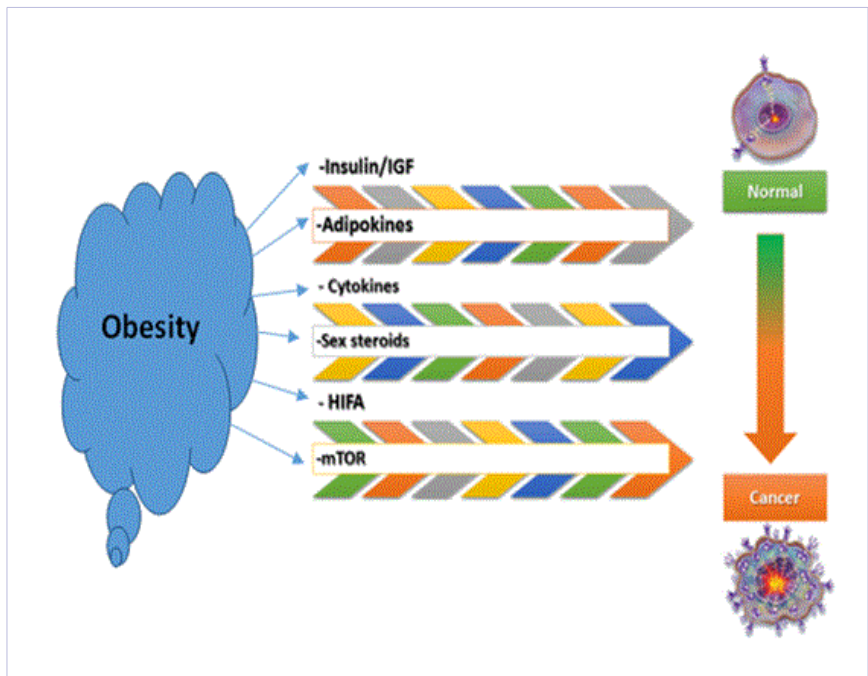

Figure 2: Linking mediators of Obesity and Cancer

\section{Adipokines}

WAT is a dynamically active endocrinal organ; it is not, as previously thought, such a fuel reservoir. It is capable of synthesizing and secreting a panel of hormones namely termed "adipokines" [59]. Adipokines are regulatory hormones for caloric intake and metabolism, as well as having a pivotal role in angiogenesis and cell growth. Through their subtypes, leptin, visfatin, resistin and adiponectin, they seem to play important roles in the pathophysiology of development of cancer and its progression [61-63].

Leptin is considered as central mediator of a feedback loop, which regulates appetite and energy homeostasis [64]. The central nervous system is the major physiological site of leptin action; however, expression of leptin receptor (OBR; also known as LEPR) is also observed at lower levels of leptin in peripheral tissues in case of obesity [65]. Chronic over expression of leptin enhances leptin resistance, resulting in increased circulating leptin levels, in a similar way to insulin resistance that is associated with raised adiposity [66]. The close correlation between adiposity, leptin levels and expression of OBR may propose a role for this neuroendocrine hormone in promoting cancer development and progression. Several studies have displayed an over expression of leptin OBR in various cancers, including breast, prostate and colon cancer $[67,68]$. Furthermore, high level of circulating leptin in obese females has been documented to increase the risk of breast cancer in post-menopausal females $[69,70,71]$. Increased leptin levels in obese subjects is reported to have mitogenic and anti-apoptotic effects and differential roles in regulation of cell migration in certain cancers included within the list of obesity linked cancers, such as breast, ovarian, prostate, endometrium, colon and thyroid cancers [72-75]. Contribution of leptin in tumor development and progression has been displayed by various signaling mechanisms. Leptin signals via a trans membrane receptor (LRb) control STAT3 and ERK activation [76]. Leptin induces STAT3 phosphorylation in the human breast cancer line, MCF7and blocking phosphorylation with the specific inhibitor 
AG490 abolished leptin-induced proliferation [77]. Furthermore, leptin increases HER2 protein levels through a STAT3 mediated upregulation of Hsp90 in breast cancer cells. Inhibition of the STAT3 signaling cascade by AG490 abrogated leptin induced HER2 expression [78]. Activation of leptin receptors leads to phosphorylation of MAPK and increased proliferation in MCF7 breast cancer cells [79]. Chronic elevation of leptin also causes ERK1/2 activation in human breast cancer cells additionally, Akt phosphorylation in human prostate cancer cells $[72,80]$.

Adiponectin is the most abundant adipokine, secreted only by mature adipocytes and has anti-inflammatory activity [81], it regulate carbohydrate and lipid metabolism, enhancing insulin sensitivity [82]. Adiponectin serum levels were thought to have an inverse association with BMI. Epidemiologic and preclinical data propose a protective effect for increased adiponectin levels on obesity-related cancer risk [83].Thus, adiponectin was proposed to have anti-tumor effect and levels of adiponectin were inversely related to risk for several cancers such as, postmenopausal breast cancer, renal cell carcinoma, prostate, endometrial and colorectal cancer [70,84 -87]. Adiponectin promotes apoptosis, induce expression of p53, inhibits expression of Bcl-2, additionally it activates AMPK pathway but inactivates ERK1 and ERK2 [88]. Mechanisms mediate anti-carcinogenic and anti-proliferative effects of adiponectin were impaired experimentally via blocking of its receptors AdipoR1 [89]. Adiponectin antagonizes carcinogenic effect of leptin on hepatocellular carcinoma cells through increase of phosphorylation of JNK, stimulation of apoptotic mediators and inhibition of mTOR phosphorylation mechanisms [90]. Another report claimed that pleiotropic effects of adiponectin are arbitrated to altered ceramide to sphingosine ratio with rise of ceramidase levels and activity [91].

Several adipokines have been identified and are suggested to be involved in obesity-related cancers, for example; resistin, visfatin, thrombopoietin and growth-related oncogene factor $\alpha$. Their levels were found to be increased in obese subjects and are anticipated to promote carcinogenesis, progression and metastasis via enhancing angiogenesis, proliferative and antiapoptotic activity [92-94].

\section{Hypoxia and angiogenesis}

Obesity modifies physiological functions of WAT, resulting in a state of low-grade inflammation and leading to expansion of adipocytes and their vasculature, with decrease of oxygen perfusion and subsequently localized hypoxia [95]. Nevertheless, there is no increase in cardiac output or blood flow to the adipose tissue, particularly to WAT [96-98]. Previous studies on animal models revealed lower levels of oxygen in WAT in obese mice when compared with lean mice [99]. Lack of oxygen results in activation of hypoxia induced factor 1-alpha $(\mathrm{HIF}-1 \alpha)$, that is a heterodimeric transcriptional factor that mainly targets and controls certain angiogenesis promoting genes such as vascular endothelial growth factor A (VEGF-A), fibroblast growth factor (FGF), Thrombospodin-1 (TSP-1) and angiogenesis prohibiting genes as plasminogen activator inhibitor, matrix metalloproteinases MMP-2 and MMP-9. Once
HIF- $1 \alpha$ transcription factor is secreted by hypoxic adipocytes, it will stimulate pro-angiogenesis process [100]. HIF- $1 \alpha$ mediates cellular responses to hypoxia via regulation of glucose uptake and stimulation of anaerobic oxidation [101]. Expression of HIF-1 $\alpha$ is reported to be increased in adipose tissue of obese individuals, and over-expression of it is reported in certain cancers and positively correlated with mortality and unresponsiveness to therapy $[102,103]$. Thus, it is possible that hypoxia through an angiogenic role, may interconnect obesity with cancer, HIF-1 $\alpha$ as a mediator of hypoxia, has another crucial role in controlling genes involved in cell survival and increased metastatic potential as well [104]. Hyperplasia of hypoxic adipose tissue, that are merely occurring in obesity, resulting in proliferation of vascular stromal cells and angiogenesis, is well confirmed as an early mechanism for cancer development and metastasis [105]. Thus, it may be the missing link between the adipose tissue progenitors of vascular stromal cells that could promote cancer development and progression through angiogenesis, endocrine or paracrine signaling to malignant cells [106].In fact, hypoxia of adipose tissue in obese subjects and the released mediator; HIF- $1 \alpha$ may be a well-recognized explanation of obesity- associated cancers.

\section{Metaflammation}

Obesity stimulates an inflammatory status that is called "Metaflammation", which is characterized by being a lowgrade, metabolically linked and chronically acting inflammatory process [107]. Despite of it is unclear, how this inflammatory state is started? One suggested mechanism is hypoxia. Through weight gain and expansion of adipose tissue, cells are too distant from the organ's vasculature causing them to become poorly oxygenated and resulting in hypoxia in the area of this event [108]. Such inflammatory condition occurs due to release HIF- $1 \alpha$, that mediates the infiltration of macrophages and monocytes into adipose tissue, and stimulates secretion of tumor necrosis factor- $\alpha$ (TNF- $\alpha$ ) from WAT [60]. TNF- $\alpha$ was found to mediate endotoxininduced tumor necrosis, cancer angiogenesis additionally it has been involved in metastasis [109-111]. Therefore, increasing levels of TNF $\alpha$ in the bloodstream of obese subjects is one of potential mechanism of TNF- $\alpha$-induced carcinogenesis [112]. Obesity-induced inflammation involves the activation of the nuclear transcription factor NF- $\mathrm{KB}$ by inactivating the inhibitor of NF- $\kappa B$ (I $\kappa B$ ) thus, inhibiting apoptosis and allowing cell survival [113].This pathway has been shown to be implicated in the development and progression of cancer [114]. Moreover, stimulation of NF- $\mathrm{BB}$ in cancer cells is able to activate cell cycling through c-Myc and cyclin D1, resulting of increased cell growth and proliferation, association between obesity-induced inflammation and the stimulation of NF- $\mathrm{BB}$ by TNF- $\alpha$ are wellestablished, however, other roles of NF- $\mathrm{KB}$ in obesity-associated cancers is still unknown. Interleukin-6 (IL-6) is another cytokine shown to be raised in obesity and IL- 6 levels are positively associated with BMI $[112,115]$. IL-6 induce JAK-STAT3 signal transduction cascade and stimulate cell proliferation, that has been suggested to act through The Mitogen-Activated Protein Kinase (MAPK) pathway, thus, pointing to the integral role of IL-6 in cell proliferation, differentiation and metastases, associated 
with inflammation in obesity-linked cancers [116,117]. Metaflammation state is correlated to abnormally high levels of cytokines and concomitant activation of pro-inflammatory mediators which might be important inducers for progression of cancer cells [23].

\section{Insulin resistance and growth Factors}

One of the proposed mechanisms that explain association between obesity and cancer is insulin resistance or low sensitivity for insulin hormone. Increased adiposity and body weight are directly correlated with insulin resistance that is compensated by over stimulation of insulin secretion, resulting in hyperinsulinemia. High serum levels of insulin is potentially promoting aggressiveness of certain cancers such as postmenopausal breast and endometrial cancer $[7,118]$. Insulin hormone when excreted within normal values under physiological conditions has an anabolic and anti-mitotic effect, however only when excreted in excess or higher values, as in obesity associated with hyperinsulinemia or insulin resistance, it has an obvious mitogenic effect [55]. Binding of insulin to its own Insulin Receptor (IR) triggers both phosphatidylinositol-3 kinase and Extracellular-signal Regulated Kinase (ERK), IR is highly expressed in adipose tissue and interestingly, over expressed in breast cancer cells and most of haematopoietic cancer cells $[119,120]$. Receptor for IGF-I (IGF-IR) has shown more than fifty percentage homology with IR and sequence similarity of about $85 \%$ for their tyrosine kinase domain, therefore both hormones could interact with any one of both receptors [118]. Binding and activation of IGF-IR results in phosphorylation of IRS proteins, which stimulate the oncogenic Ras-MAPK and PI3K-Akt signaling pathways, Signaling pathway of the PI3K-Akt induces cell proliferation and is frequently activated in cancers [121,122]. Another downstream signaling molecule of Akt is mTOR, which stimulates protein translation and cancer growth [68]. Furthermore, tumors with constitutive stimulation of the PI3K pathway are insensitive to dietary restrictions, which can normally delay the incidence and decrease growth of various tumor types by decreasing the levels of circulating insulin and IGF-1, suggesting an association between obesity and cancer [123]. Insulin resistance and consequent hyperinsulinemia that accompany obesity, diabetes type 2 and metabolic syndrome serve to facilitate glucose uptake by muscle, fat, and liver mediated by insulin receptors. Elevated levels of insulin may also stimulate mitogenesis and growth in a number of tissues and may also increase IGF-1 and decrease IGF binding proteins, thereby providing higher levels of biologically active IGF-1 proteins, which further interact with cell-surface receptors to stimulate tumor growth and may induce carcinogenesis.

\section{Sex steroids}

Post-menopausal breast cancer risk was reported to be increased in women with high serum levels of sex hormones, such as, Dehydroepiandrosterone (DHEA), testosterone, estrone, and estradiol $[124,125]$. Sex hormones may directly mediate the effect of obesity on cancer through activating growth and progression of tumor cells , in particular breast, and endometrial tumors [126,127]. Mechanisms meditating carcinogenic effects of estrogen may be related to induction of DNA damage, regulation of expression of insulin receptor IRS- 1 in the breast or/and genetic instability [128]. In addition, estrogen stimulates cellular proliferation and angiogenesis [129].Several studies have documented a positive correlation between heightened circulating estrogen levels and the risk of postmenopausal breast cancer $[124,130]$. Production of estrogens after menopause, mostly takes place in the peripheral adipose tissues, catalyzed by cytochrome P450 dependent enzyme; aromatase enzyme, that converts androgen precursors into estrogens. CYP19 is the gene encoding aromatase and it is thought to be induced in postmenopausal women and not in premenopausal females $[16,131]$. Therefore, the greater risk of hormone receptor positive breast cancer in a post menopause period of overweight/obese women has been referred, in particular, to elevated estrogen production in adipose tissue by aromatase enzyme as a consequence of hyper adiposity [132].

To date, the specific mechanism by which postmenopausal women, but not pre-menopausal women, have an obesity-related risk of breast cancer has not been fully clarified. Production of estrogen differs significantly between premenopausal and post-menopausal women. The main source of estrogen production in pre-menopausal women is the ovaries; whereas, for post-menopausal women, it is from peripheral aromatization in adipose tissue [32]. In post-menopausal women, fat cells aromatize ovarian and adrenal androgens into estrogen. It has been demonstrated that elevated circulating levels of free estrogen, as well as estrone and androgens, are associated with breast cancer [31]. Therefore, Increased BMI has been associated with increased the risk of postmenopausal breast cancer not premenopausal breast cancer $[16,34,131]$.

Similarly, heightened concentrations of plasma estradiol and estrone observed in endometrial cancer are associated with increased cancer risk in postmenopausal obese women due to activation of aromatase enzyme, in expanded adipose tissue due to obesity, converting androgens into estradiol and estrone [40]. Elevated levels of estradiol induces endometrial cell proliferation, blocks apoptosis and at the same time encourages IGF-I synthesis within endometrial tissue [23]. In a reverse manner, elevated BMI in premenopausal women, decreases breast cancer risk [126]. While , EPIC study and other epidemiological studies have reported that elevated plasma levels of androgens are correlated with increased risk of breast cancer in both pre- and postmenopausal women, therefore proposing that androgens may also be considered as links between obesity and breast cancer $[20,125]$.

\section{Oxidative stress}

As disused before, obese patients usually exhibited lower levels of antioxidant enzymes and increased concentrations of oxidative stress byproducts. Obesity causes elevation of the sizes and activities of adipocytes, which in turn leads to liberation of inflammatory molecules as Interleukins and. Monocyte Chemoattractant Protein-1 (MCP-1), causing tissue necrosis 
and subsequent accumulation of activated macrophages. This pro-inflammatory status stimulates, in turn, insulin resistance development, over production of Reactive Oxygen Species (ROS) and induction of oxidative stress and modification of critical macromolecules and, finally, carcinogenesis. Heightened levels of ROS proceed to increased susceptibility to mutagenic factors leading to mutations with DNA damage and carcinogenesis [133-135]. Increased ROS are also contributed to enhancement of proliferation by transactivation of the tyrosine kinase receptor through ligand-independent mechanism, and finally, promoting spread of cancer cells and metastasis into distant organs [136,137]. Besides, ROS may contribute to stabilization of HIF1 $\alpha$ that promote tumor angiogenesis allowing potentiation of carcinogenic effect of ROS [138-140]. Elevation of circulating levels or local ROS present within the tumor environment that were derived from increased adiposity and obesity accelerate oxidative stress within tumor cells and contribute to increased risk for cancer progression in patients with obesity [141]. Interaction of chronic inflammatory status; metaflammation in obese subjects with hypoxia of WAT may be one of the proposed mechanisms for increasing systemic oxidative stress, thus antioxidant activities may be independently decreased with subsequent increased oxidative damage to DNA, which may heighten cancer risk.

\section{Epigenetic changes}

Epigenetics are dealing with mechanisms beyond genomic or DNA-based alteration at genome such as genetic mutation and transcription factor targeting. Casual factors for epigenetic changes include disparity in DNA or environmental factors such as diet, and dietary supplements, stress, exercise, and exposure to chemicals. Interestingly epigenetic changes could affect susceptibility or risk for diseases, representing a common linking mechanism between disease and environment [142].Recently, epigenetic modifications has been proposed as a linking mechanism between obesity and cancer. However, lack of detailed interpretation of the epigenetic regulatory pathways perturbed by environmental and causal factors may be an obstacle for comprehensive understanding of that mechanism [143]. Epigenetic mechanisms regulate gene expression by coordinating and controlling the levels and activities of the so called highly conserved genomic processing, they include DNA methylation, post-translation histone covalent amendments, chromatin remodeling factors, and noncoding, micro RNAs or regulatory RNAs [144]. Previous reports demonstrated that BMI was associated to immunological alterations related to IGF signaling pathway and involvement of inflammation and angiogenesis as possible carcinogenic events in obesity, one study documented an association of increased BMI with positive expression IGFIR mRNA only in postmenopausal breast cancer but not among premenopausal patients $[145,146]$. Recently positive association of BMI with multiple epigenetic modifications was demonstrated in Estrogen Receptor (ER) positive breast cancer patients, they identified such association between BMI with methylation of the genes involved in immunological response, insulin like growth factor pathway and DNA repair process. In addition, they identified particle sites; SH3BP2, IGFBP6, DNMT3, and ERCC6 as being most significantly associated with BMI in ER positive breast cancer patients [147]. In Epigenome Wide Association Study (EWAS), a positive association has been demonstrated between BMI and methylation of DNA within HIF3A intron, that was proposed to be involved in hypoxia, low grade inflammatory state and carcinogenesis in obesity [148]. Representing a complexity and interactions between DNA methylation, genotype, age and disease. Increased BMI in European adults was found to be associated in a positive manner with increased methylation at HIF3A1 locus, providing supporting evidence of the crucial role of HIF signaling in mediating comorbidities associated with obesity and increased BMI [148].

In spite of the huge development of recent technologies for assessment of epigenetic mechanisms, however the interpretation of such of epigenetic findings or the confirmation of their biological relevance remains a significant challenge. This is in part may point to the complexity of epigenetic mechanisms or the gaps in our understanding of how several epigenetic mechanisms may interact all together to regulate gene expression or induce molecular events as carcinogenesis in obesityassociated cancers .

\section{Conclusion}

The pandemic of obesity is expanding all over the world and raising prevalence of obesity has significantly increased the risk of certain types of cancer. There is growing evidences supporting that obesity is associated with an increased risk of certain cancers such as postmenopausal, endometrial, esophageal, liver, gall bladder, prostate, colorectal and pancreatic cancer. Although some of these associations can be due to changes in hormones, dietary or environmental factors associated with obesity, however varieties of tumor types, suggesting that other crucial mechanisms may trigger that association. It has been postulated that the mechanisms by which obesity may promote cancer include: adipokines secreted by the adipocyte, for example, increased levels of leptin, resistin, visfatin and inflammatory cytokine and decreased adiponectin. Hypoxia and angiogenesis commenced due to expansion with hypo perfusion of enlarged adipocytes could be another triggering mechanism for carcinogenesis. Hyperinsulinemia and increase levels of IGF may potentiate the proliferation process. Recently, epigenetic modifications has been proposed as a linking mechanism between obesity and cancer, including DNA methylation, histone modification and chromatin remodeling factors. It is likely that many of these mechanisms cooperate with each other and with other environmental factors to result in multiple 'knockouts' which are needed for carcinogenesis. However, it remains uncertain how the merging of these events drives obesity-linked cancer. Thus, it is still a matter of controversial, whether targeting therapies for these mechanisms could prevent effects of obesity on cancer or carcinogenic effect of obesity. 


\section{References}

1. Berger NA. Ann N Y Acad Sci. 2014;1311:57-76.

2. Smith KB, Smith MS. Obesity Statistics. Prim Care. 2016;43(1):121135, ix.

3. Anderson AS, Key TJ, Norat T, Scoccianti C, Cecchini M, Berrino F, et al. European Code against Cancer 4th Edition: Obesity, body fatness and cancer. Cancer Epidemiol. 2015;39 Suppl 1:S34-45.

4. Mitchell S, Shaw D. The worldwide epidemic of female obesity. Best Pract Res Clin Obstet Gynaecol. 2015;29(3):289-299.

5. Bruno E, Gargano G, Villarini A, Traina A, Johansson H, Mano MP, et al. Adherence to WCRF/AICR cancer prevention recommendations and metabolic syndrome in breast cancer patients. Int J Cancer 2016;138(1):237-244.

6. Kushi LH, Byers T, Doyle C, Bandera EV, McCullough M, McTiernan A, et al. American Cancer Society Guidelines on Nutrition and Physical Activity for cancer prevention: reducing the risk of cancer with healthy food choices and physical activity. CA Cancer J Clin. 2006;56(5):25481; quiz 313-314.

7. Kushi LH, Doyle C, McCullough M, Rock CL, Demark-Wahnefried W, Bandera EV, et al. American Cancer Society Guidelines on Nutrition and Physical Activity for cancer prevention: reducing the risk of cancer with healthy food choices and physical activity. CA Cancer J Clin. 2012;62(1):30-67.

8. Makarem N, Lin Y, Bandera EV, Jacques PF, Parekh N. Concordance with World Cancer Research Fund/American Institute for Cancer Research (WCRF/AICR) guidelines for cancer prevention and obesityrelated cancer risk in the Framingham Offspring cohort (1991-2008). Cancer Causes Control. 2015;26(2):277-286.

9. Heggie SJ, Wiseman MJ, Cannon GJ, Miles LM, Thompson RL, Stone EM, et al. Defining the state of knowledge with respect to food, nutrition, physical activity, and the prevention of cancer. J Nutr. 2003;133(11 Suppl 1):3837S-3842S.

10. Tewari R, Rajender S, Natu SM, Dalela D, Goel A, Goel MM, et al Diet, obesity, and prostate health: are we missing the link? J Androl. 2012;33(5):763-776.

11. Argolo DF, Iyengar NM, Hudis CA. Erratum to: Obesity and Cancer: Concepts and Challenges. Indian J Surg Oncol. 2015;6(4):399.

12. Iyengar NM, Kochhar A, Morris PG, Morris LG, Zhou XK, Ghossein RA, et al. Impact of obesity on the survival of patients with early-stage squamous cell carcinoma of the oral tongue. Cancer. 2014;120(7):983991.

13. Berger NA. Obesity-associated gastrointestinal tract cancer: from beginning to end. Cancer. 2014;120(7):935-939.

14. González Svatetz CA, Goday Arnó A. Obesity and cancer: “Dangerous friendship”. Medicina Clínica (English Edition) 2015;145:24-30.

15. Handelsman Y, Leroith D, Bloomgarden ZT, Dagogo-Jack S, Einhorn D, Garber AJ, et al. Diabetes and cancer--an AACE/ACE consensus statement. Endocr Pract. 2013;19(4):675-693.

16. Anderson GL, Neuhouser ML. Obesity and the risk for premenopausal and postmenopausal breast cancer. Cancer Prev Res (Phila). 2012;5(4):515-521.

17. Amadou A, Ferrari P, Muwonge R, Moskal A, Biessy C, Romieu I, et al. Overweight, obesity and risk of premenopausal breast cancer according to ethnicity: a systematic review and dose-response metaanalysis. Obes Rev. 2013;14(8):665-678.
18. Warburg 0. On the origin of cancer cells. Science 1956;123:309-314.

19. Vainio H, Kaaks R, Bianchini F. Weight control and physical activity in cancer prevention: international evaluation of the evidence. Eur J Cancer Prev 2002;11 Suppl 2:S94-100.

20. Reeves GK, Pirie K, Beral V, Green J, Spencer E, Bull D. Cancer incidence and mortality in relation to body mass index in the Million Women Study: cohort study. BMJ 2007;335:1134.

21.Calle EE, Rodriguez C, Walker-Thurmond K, Thun MJ. Overweight, obesity, and mortality from cancer in a prospectively studied cohort of U.S. adults. N Engl J Med 2003;348:1625-1638.

22. Bergstrom A, Pisani P, Tenet V, Wolk A, Adami HO. Overweight as an avoidable cause of cancer in Europe. Int J Cancer 2001;91:421-430.

23. Calle EE, Kaaks R. Overweight, obesity and cancer: epidemiological evidence and proposed mechanisms. Nat Rev Cancer 2004;4:579-591.

24. Calle EE, Thun MJ. Obesity and cancer. Oncogene 2004;23:6365-6378.

25.Wiseman M. The second World Cancer Research Fund/American Institute for Cancer Research expert report. Food, nutrition, physical activity, and the prevention of cancer: a global perspective. Proc Nutr Soc. 2008;67(3):253-256.

26. Kitahara CM, Platz EA, Freeman LE, Hsing AW, Linet MS, Park Y, et al. Obesity and thyroid cancer risk among U.S. men and women: a pooled analysis of five prospective studies. Cancer Epidemiol Biomarkers Prev. 2011;20(3):464-472.

27. Lichtman MA. Obesity and the risk for a hematological malignancy: leukemia, lymphoma, or myeloma. Oncologist. 2010;15(10):10831101.

28. Donohoe CL, Pidgeon GP, Lysaght J, Reynolds JV. Obesity and gastrointestinal cancer. Br J Surg. 2010;97(5):628-642.

29. Wolk A, Gridley G, Svensson M, Nyren O, McLaughlin JK, Fraumeni JF, et al. A prospective study of obesity and cancer risk (Sweden). Cancer Causes Control 2001;12:13-21.

30. Freedland SJ, Platz EA. Obesity and prostate cancer: making sense out of apparently conflicting data. Epidemiol Rev 2007;29:88-97.

31. Trentham-Dietz A, Newcomb PA, Nichols HB, Hampton JM. Breast cancer risk factors and second primary malignancies among women with breast cancer. Breast Cancer Res Treat 2007;105:195-207.

32. Trentham-Dietz A, Newcomb PA, Egan KM, Titus-Ernstoff L, Baron JA, Storer BE, et al. Weight change and risk of postmenopausal breast cancer (United States). Cancer Causes Control 2000;11:533-542.

33. Harvie M, Hooper L, Howell AH. Central obesity and breast cancer risk: a systematic review. Obes Rev 2003;4:157-173.

34. Renehan AG, Tyson M, Egger M, Heller RF, Zwahlen M. Body-mass index and incidence of cancer: a systematic review and meta-analysis of prospective observational studies. Lancet. 2008;371(9612):569578.

35. Giacosa A, Franceschi S, La Vecchia C, Favero A, Frascio F, Andreatta R. Overweight and colorectal cancer risk. Minerva Gastroenterol Dietol 2001; $47: 235-240$

36. Campbell PT, Jacobs ET, Ulrich CM, Figueiredo JC, Poynter JN, McLaughlin JR, et al. Case-control study of overweight, obesity, and colorectal cancer risk, overall and by tumor microsatellite instability status. J Natl Cancer Inst. 2010;102(6):391-400.

37. Chow WH, Blot WJ, Vaughan TL, Risch HA, Gammon MD, Stanford JL, et al. Body mass index and risk of adenocarcinomas of the esophagus and 
gastric cardia. J Natl Cancer Inst 1998;90:150-155

38. Kubo A, Corley DA. Body mass index and adenocarcinomas of the esophagus or gastric cardia: a systematic review and meta-analysis. Cancer Epidemiol Biomarkers Prev 2006;15:872-878.

39. Chow WH, Finkle WD, McLaughlin JK, Frankl H, Ziel HK, Fraumeni JF Jr. The relation of gastroesophageal reflux disease and its treatment to adenocarcinomas of the esophagus and gastric cardia. JAMA 1995;274:474-477.

40. Kaaks R, Lukanova A, Kurzer MS. Obesity, endogenous hormones, and endometrial cancer risk: a synthetic review. Cancer Epidemiol Biomarkers Prev 2002;11:1531-1543.

41. Nair S, Mason A, Eason J, Loss G, Perrillo RP. Is obesity an independent risk factor for hepatocellular carcinoma in cirrhosis? Hepatology 2002;36:150-155.

42. Caldwell SH, Crespo DM, Kang HS, Al-Osaimi AM. Obesity and hepatocellular carcinoma. Gastroenterology 2004;127:S97-103.

43. MacInnis RJ, English DR. Body size and composition and prostate cancer risk: systematic review and meta-regression analysis. Cancer Causes Control 2006;17:989-1003.

44. MacInnis RJ, English DR, Gertig DM, Hopper JL, Giles GG. Body size and composition and prostate cancer risk. Cancer Epidemiol Biomarkers Prev. 2003;12(12):1417-1421.

45. Bonn SE, Wiklund F, Sjolander A, Szulkin R, Stattin P, Holmberg E, et al. Body mass index and weight change in men with prostate cancer: progression and mortality. Cancer Causes Control. 2014;25(8):933943.

46. Cantarutti A, Bonn SE, Adami HO, Gronberg H, Bellocco R, Balter K. Body mass index and mortality in men with prostate cancer. Prostate. 2015;75(11):1129-1136

47. Ma J, Li H, Giovannucci E, Mucci L, Qiu W, Nguyen PL, et al. Prediagnostic body-mass index, plasma C-peptide concentration, and prostate cancer-specific mortality in men with prostate cancer: a long-term survival analysis. Lancet Oncol. 2008;9(11):1039-1047.

48. Larsson SC, Permert J, Hakansson N, Naslund I, Bergkvist L, Wolk A Overall obesity, abdominal adiposity, diabetes and cigarette smoking in relation to the risk of pancreatic cancer in two Swedish populationbased cohorts. Br J Cancer 2005;93:1310-1315.

49. Chow WH, Dong LM, Devesa SS. Epidemiology and risk factors for kidney cancer. Nat Rev Urol. 2010;7(5):245-257.

50. Komura K, Inamoto T, Black PC, Koyama K, Katsuoka Y, Watsuji T, et al. Prognostic significance of body mass index in Asian patients with localized renal cell carcinoma. Nutr Cancer. 2011;63(6):908-915.

51. Rogde AJ, Gudbrandsdottir G, Hjelle KM, Sand KE, Bostad L, Beisland C. Obesity is associated with an improved cancer-specific survival, but an increased rate of postoperative complications after surgery for renal cell carcinoma. Scand J Urol Nephrol. 2012;46(5):348-357.

52. Steffens S, Ringe KI, Schroeer K, Lehmann R, Rustemeier J, Wegener G, et al. Does overweight influence the prognosis of renal cell carcinoma? Results of a multicenter study. Int J Urol. 2013;20(6):585-592.

53. Bandera EV, Kushi LH, Rodriguez-Rodriguez L. Nutritional factors in ovarian cancer survival. Nutr Cancer. 2009;61(5):580-586.

54. Wolin KY, Carson K, Colditz GA. Obesity and cancer. Oncologist. 2010;15(6):556-565.

55. De Pergola G, Silvestris F. Obesity as a major risk factor for cancer. J Obes. 2013;2013:291546.
56. Albanes D, Weinstein SJ, Wright ME, Mannisto S, Limburg PJ, Snyder K, et al. Serum insulin, glucose, indices of insulin resistance, and risk of prostate cancer. J Natl Cancer Inst. 2009;101(18):1272-1279.

57. Roberts DL, Dive C, Renehan AG. Biological mechanisms linking obesity and cancer risk: new perspectives. Annu Rev Med. 2010;61:301-316.

58. Chen Y, Wang X, Wang J, Yan Z, Luo J. Excess body weight and the risk of primary liver cancer: an updated meta-analysis of prospective studies. Eur J Cancer. 2012;48(14):2137-2145.

59. Scherer PE. Adipose tissue: from lipid storage compartment to endocrine organ. Diabetes. 2006;55(6):1537-1545.

60. van Kruijsdijk RC, van der Wall E, Visseren FL. Obesity and cancer: the role of dysfunctional adipose tissue. Cancer Epidemiol Biomarkers Prev. 2009;18(10):2569-2578.

61. Fischer-Posovszky P, Wabitsch M, Hochberg Z. Endocrinology of adipose tissue - an update. Horm Metab Res. 2007;39(5):314-321.

62. Tilg H, Moschen AR. Adipocytokines: mediators linking adipose tissue, inflammation and immunity. Nat Rev Immunol. 2006;6(10):772-783.

63. Hursting SD, Digiovanni J, Dannenberg AJ, Azrad M, Leroith D, Demark-Wahnefried $\mathrm{W}$, et al. Obesity, energy balance, and cancer: new opportunities for prevention. Cancer Prev Res (Phila). 2012;5(11):1260-1272.

64. Park HK, Ahima RS. Physiology of leptin: energy homeostasis, neuroendocrine function and metabolism. Metabolism. 2015;64(1):2434.

65. Cohen P, Zhao C, Cai X, Montez JM, Rohani SC, Feinstein P, et al. Selective deletion of leptin receptor in neurons leads to obesity. J Clin Invest. 2001;108(8):1113-1121.

66. Friedman JM, Halaas JL. Leptin and the regulation of body weight in mammals. Nature. 1998;395(6704):763-770.

67. Schubbert S, Shannon K, Bollag G. Hyperactive Ras in developmental disorders and cancer. Nat Rev Cancer. 2007;7(4):295-308.

68. Zoncu R, Efeyan A, Sabatini DM. mTOR: from growth signal integration to cancer, diabetes and ageing. Nat Rev Mol Cell Biol. 2011;12(1):2135 .

69. Wu MH, Chou YC, Chou WY, Hsu GC, Chu CH, Yu CP, et al. Circulating levels of leptin, adiposity and breast cancer risk. Br J Cancer. 2009;100(4):578-582.

70. Assiri AM, Kamel HF, Hassanien MF. Resistin, visfatin, adiponectin, and leptin: risk of breast cancer in pre- and postmenopausal saudi females and their possible diagnostic and predictive implications as novel biomarkers. Dis Markers. 2015;2015:2019.

71. Ollberding NJ, Kim Y, Shvetsov YB, Wilkens LR, Franke AA, Cooney $\mathrm{RV}$, et al. Prediagnostic leptin, adiponectin, C-reactive protein, and the risk of postmenopausal breast cancer. Cancer Prev Res (Phila). 2013;6(3):188-195

72. Hoda MR, Popken G. Mitogenic and anti-apoptotic actions of adipocyte-derived hormone leptin in prostate cancer cells. BJU Int. 2008;102(3):383-388.

73. Ptak A, Kolaczkowska E, Gregoraszczuk EL. Leptin stimulation of cell cycle and inhibition of apoptosis gene and protein expression in OVCAR-3 ovarian cancer cells. Endocrine. 2013;43(2):394-403.

74. Drew JE. Molecular mechanisms linking adipokines to obesity-related colon cancer: focus on leptin. Proc Nutr Soc. 2012;71(1):175-180.

75. Cheng SP, Yin PH, Chang YC, Lee CH, Huang SY, Chi CW. Differential 
roles of leptin in regulating cell migration in thyroid cancer cells Oncol Rep. 2010;23(6):1721-1727.

76. Banks AS, Davis SM, Bates SH, Myers MG, Jr. Activation of downstream signals by the long form of the leptin receptor. J Biol Chem. 2000;275(19):14563-14572.

77. Saxena NK, Vertino PM, Anania FA, Sharma D. leptin-induced growth stimulation of breast cancer cells involves recruitment of histone acetyltransferases and mediator complex to CYCLIN D1 promoter via activation of Stat3. J Biol Chem. 2007;282(18):13316-13325.

78. Giordano C, Vizza D, Panza S, Barone I, Bonofiglio D, Lanzino M, et al. Leptin increases HER2 protein levels through a STAT3-mediated upregulation of Hsp90 in breast cancer cells. Mol Oncol. 2013;7(3):379391.

79. Dieudonne MN, Machinal-Quelin F, Serazin-Leroy V, Leneveu MC, Pecquery R, Giudicelli Y. Leptin mediates a proliferative response in human MCF7 breast cancer cells. Biochem Biophys Res Commun 2002;293(1):622-628.

80. Catalano S, Mauro L, Marsico S, Giordano C, Rizza P, Rago V, et al. Leptin induces, via ERK1/ERK2 signal, functional activation of estrogen receptor alpha in MCF-7 cells. J Biol Chem. 2004;279(19):1990819915.

81. Renehan AG, Zwahlen M, Egger M. Adiposity and cancer risk: new mechanistic insights from epidemiology. Nat Rev Cancer 2015;15(8):484-498.

82. Hu E, Liang P, Spiegelman BM. AdipoQ is a novel adipose-specific gene dysregulated in obesity. J Biol Chem. 1996;271(18):10697-10703.

83. Grossmann ME, Nkhata KJ, Mizuno NK, Ray A, Cleary MP. Effects of adiponectin on breast cancer cell growth and signaling. $\mathrm{Br} \mathrm{J}$ Cancer 2008;98(2):370-379.

84. Bub JD, Miyazaki T, Iwamoto Y. Adiponectin as a growth inhibitor in prostate cancer cells. Biochem Biophys Res Commun 2006;340(4):1158-1166.

85. Gong TT, Wu QJ, Wang YL, Ma XX. Circulating adiponectin, leptin and adiponectin-leptin ratio and endometrial cancer risk: Evidence from a meta-analysis of epidemiologic studies. Int J Cancer 2015;137(8):1967-1978

86. Li ZJ, Yang XL, Yao Y, Han WQ Li BO. Circulating adiponectin levels and risk of endometrial cancer: Systematic review and meta-analysis. Exp Ther Med. 2016;11(6):2305-2313.

87. Kaklamani VG, Wisinski KB, Sadim M, Gulden C, Do A, Offit K, et al. Variants of the adiponectin (ADIPOQ) and adiponectin receptor 1 (ADIPOR1) genes and colorectal cancer risk. JAMA. 2008;300(13):1523-1531.

88. Dieudonne MN, Bussiere M, Dos Santos E, Leneveu MC, Giudicelli Y Pecquery R. Adiponectin mediates antiproliferative and apoptotic responses in human MCF7 breast cancer cells. Biochem Biophys Res Commun. 2006;345(1):271-279.

89. Kim AY, Lee YS, Kim KH, Lee JH, Lee HK, Jang SH, et al. Adiponectin represses colon cancer cell proliferation via AdipoR1- and -R2mediated AMPK activation. Mol Endocrinol 2010;24:1441-1452.

90.Sharma D, Wang J, Fu PP, Sharma S, Nagalingam A, Mells J, et al. Adiponectin antagonizes the oncogenic actions of leptin in hepatocellular carcinogenesis. Hepatology. 2010;52(5):1713-1722.

91. Holland WL, Miller RA, Wang ZV, Sun K, Barth BM, Bui HH, et al. Receptor-mediated activation of ceramidase activity initiates the pleiotropic actions of adiponectin. Nat Med. 2011;17(1):55-63.
92. Maury E, Brichard SM, Pataky Z, Carpentier A, Golay A, BobbioniHarsch E. Effect of obesity on growth-related oncogene factor-alpha, thrombopoietin, and tissue inhibitor metalloproteinase-1 serum levels. Obesity (Silver Spring). 2010;18(8):1503-1509.

93. Louie SM, Roberts LS, Nomura DK. Mechanisms linking obesity and cancer. Biochim Biophys Acta. 2013;1831(10):1499-1508.

94. Assiri AM, Kamel HF. Evaluation of diagnostic and predictive value of serum adipokines: Leptin, resistin and visfatin in postmenopausal breast cancer. Obes Res Clin Pract 2016;10:442-453.

95. Brahimi-Horn MC, Pouyssegur J. Oxygen, a source of life and stress. FEBS Lett. 2007;581(19):3582-3591.

96. Blaak EE, van Baak MA, Kemerink GJ, Pakbiers MT, Heidendal GA, Saris WH. Beta-adrenergic stimulation and abdominal subcutaneous fat blood flow in lean, obese, and reduced-obese subjects. Metabolism. 1995;44(2):183-187.

97. Jansson PA, Larsson A, Lonnroth PN. Relationship between blood pressure, metabolic variables and blood flow in obese subjects with or without non-insulin-dependent diabetes mellitus. Eur J Clin Invest. 1998;28(10):813-818.

98. West DB, Prinz WA, Francendese AA, Greenwood MR. Adipocyte blood flow is decreased in obese Zucker rats. Am J Physiol. 1987;253(2 Pt 2):R228-233

99. Ye J, Gao Z, Yin J, He Q. Hypoxia is a potential risk factor for chronic inflammation and adiponectin reduction in adipose tissue of ob/ob and dietary obese mice. Am J Physiol Endocrinol Metab. 2007;293(4):E1118-1128.

100. Simons M. Angiogenesis: where do we stand now? Circulation. 2005;111(12):1556-1566.

101.CarmelietP, Dor Y, HerbertJM, Fukumura D, Brusselmans K, Dewerchin $\mathrm{M}$, et al. Role of HIF-1alpha in hypoxia-mediated apoptosis, cell proliferation and tumour angiogenesis. Nature. 1998;394(6692):485490.

102.Silha JV, Krsek M, Sucharda P, Murphy LJ. Angiogenic factors are elevated in overweight and obese individuals. Int J Obes (Lond). 2005;29(11):1308-1314.

103.Breier G, Heidenreich R, Gaumann A, Groot M, Licht A, Nicolaus A, et al. Regulators of angiogenesis as targets for anti-angiogenic tumor therapy. Ann Hematol. 2002;81 Suppl 2:S71-2.

104.Mendonca F, Soares R. Obesity and cancer phenotype: Is angiogenesis a missed link? Life Sci. 2015;139:16-23.

105.Sun K, Kusminski CM, Scherer PE. Adipose tissue remodeling and obesity. J Clin Invest. 2011;121(6):2094-2101.

106.Zhang Y, Bellows CF, Kolonin MG. Adipose tissue-derived progenitor cells and cancer. World J Stem Cells. 2010;2(5):103-113

107.Gregor MF, Hotamisligil GS. Inflammatory mechanisms in obesity. Annu Rev Immunol. 2011;29:415-445.

108.Neels JG, Olefsky JM. Inflamed fat: what starts the fire? J Clin Invest. 2006;116(1):33-35

109.Carswell EA, Old LJ, Kassel RL, Green S, Fiore N, Williamson B. An endotoxin-induced serum factor that causes necrosis of tumors. Proc Natl Acad Sci U S A. 1975;72(9):3666-3670.

110.Leibovich SJ, Polverini PJ, Shepard HM, Wiseman DM, Shively V, Nuseir N. Macrophage-induced angiogenesis is mediated by tumour necrosis factor-alpha. Nature. 1987;329(6140):630-632. 
111.Orosz P, Echtenacher B, Falk W, Ruschoff J, Weber D, Mannel DN. Enhancement of experimental metastasis by tumor necrosis factor. J Exp Med. 1993;177(5):1391-1398.

112.Kern PA, Ranganathan S, Li C, Wood L, Ranganathan G. Adipose tissue tumor necrosis factor and interleukin-6 expression in human obesity and insulin resistance. Am J Physiol Endocrinol Metab. 2001;280(5):E745-51

113.Liu ZG, Hsu H, Goeddel DV, Karin M. Dissection of TNF receptor 1 effector functions: JNK activation is not linked to apoptosis while NFkappaB activation prevents cell death. Cell. 1996;87(3):565-576.

114.Calado DP, Zhang B, Srinivasan L, Sasaki Y, Seagal J, Unitt C, et al. Constitutive canonical NF-kappaB activation cooperates with disruption of BLIMP1 in the pathogenesis of activated B cell-like diffuse large cell lymphoma. Cancer Cell. 2010;18(6):580-589.

115.Duyao MP, Buckler AJ, Sonenshein GE. Interaction of an NF-kappa B-like factor with a site upstream of the c-myc promoter. Proc Nat Acad Sci U S A. 1990;87(12):4727-4731.

116.Darnell JE, Jr., Kerr IM, Stark GR. Jak-STAT pathways and transcriptional activation in response to IFNs and other extracellular signaling proteins. Science. 1994;264(5164):1415-1421.

117.Yadav A, Kumar B, Datta J, Teknos TN, Kumar P. IL-6 promotes head and neck tumor metastasis by inducing epithelial-mesenchyma transition via the JAK-STAT3-SNAIL signaling pathway. Mol Cancer Res. 2011;9(12):1658-1667.

118.Gunter MJ, Hoover DR, Yu H, Wassertheil-Smoller S, Manson JE, Li J, et al. A prospective evaluation of insulin and insulin-like growth factor-I as risk factors for endometrial cancer. Cancer Epidemiol Biomarkers Prev. 2008;17(4):921-929.

119.Frasca F, Pandini G, Sciacca L, Pezzino V, Squatrito S, Belfiore A, et al. The role of insulin receptors and IGF-I receptors in cancer and other diseases. Arch Physiol Biochem. 2008;114(1):23-37

120.Chan BT, Lee AV. Insulin receptor substrates (IRSs) and breast tumorigenesis. J Mammary Gland Biol Neoplasia. 2008;13(4):415422

121.Engelman JA. Targeting PI3K signalling in cancer: opportunities, challenges and limitations. Nat Rev Cancer. 2009;9(8):550-562.

122.Cully M, You H, Levine AJ, Mak TW. Beyond PTEN mutations: the PI3K pathway as an integrator of multiple inputs during tumorigenesis. Nat Rev Cancer. 2006;6(3):184-192.

123. Kalaany NY, Sabatini DM. Tumours with PI3K activation are resistant to dietary restriction. Nature. 2009;458(7239):725-731.

124.Kaaks R, Rinaldi S, Key TJ, Berrino F, Peeters PH, Biessy C, et al. Postmenopausal serum androgens, oestrogens and breast cancer risk: the European prospective investigation into cancer and nutrition. Endocr Relat Cancer. 2005;12(4):1071-1082.

125.Kaaks R, Berrino F, Key T, Rinaldi S, Dossus L, Biessy C, et al. Serum sex steroids in premenopausal women and breast cancer risk within the European Prospective Investigation into Cancer and Nutrition (EPIC). J Natl Cancer Inst. 2005;97(10):755-765.

126.Brown KA, Simpson ER. Obesity and breast cancer: progress to understanding the relationship. Cancer Res. 2010;70(1):4-7.

127.Allen NE, Key TJ, Dossus L, Rinaldi S, Cust A, Lukanova A, et al. Endogenous sex hormones and endometrial cancer risk in women in the European Prospective Investigation into Cancer and Nutrition (EPIC). Endocr Relat Cancer. 2008;15(2):485-497.
128.Lee AV, Jackson JG, Gooch JL, Hilsenbeck SG, Coronado-Heinsohn E, Osborne CK, et al. Enhancement of insulin-like growth factor signaling in human breast cancer: estrogen regulation of insulin receptor substrate-1 expression in vitro and in vivo. Mol Endocrinol. 1999;13(5):787-796.

129.Pequeux C, Raymond-Letron I, Blacher S, Boudou F, Adlanmerini M, Fouque MJ, et al. Stromal estrogen receptor- $\alpha$ promotes tumor growth by normalizing an increased angiogenesis. Cancer Res. 2012;72(12):3010-3019.

130.Key TJ, Appleby PN, Reeves GK, Roddam A, Dorgan JF, Longcope C, et al. Body mass index, serum sex hormones, and breast cancer risk in postmenopausal women. J Natl Cancer Inst. 2003;95(16):1218-1226.

131.Iyengar NM, Hudis CA, Dannenberg AJ. Obesity and inflammation: new insights into breast cancer development and progression. Am Soc Clin Oncol Educ Book. 2013:46-51.

132.Li CI, Daling JR, Malone KE. Incidence of invasive breast cancer by hormone receptor status from 1992 to 1998. J Clin Oncol. 2003;21(1):28-34.

133.Demark-Wahnefried W, Platz EA, Ligibel JA, Blair CK, Courneya KS, Meyerhardt JA, et al. The role of obesity in cancer survival and recurrence. Cancer Epidemiol Biomarkers Prev. 2012;21(8):12441259.

134.Feuerer M, Herrero L, Cipolletta D, Naaz A, Wong J, Nayer A, et al. Lean, but not obese, fat is enriched for a unique population of regulatory $\mathrm{T}$ cells that affect metabolic parameters. Nat Med. 2009;15(8):930-939.

135.Marnett LJ. Oxyradicals and DNA damage. Carcinogenesis 2000;21:361-370.

136.Fiaschi T, Chiarugi P. Oxidative stress, tumor microenvironment, and metabolic reprogramming: a diabolic liaison. Int J Cell Biol. 2012;2012:762825

137.Ferraro D, Corso S, Fasano E, Panieri E, Santangelo R, Borrello S, et al. Pro-metastatic signaling by c-Met through RAC-1 and reactive oxygen species (ROS). Oncogene. 2006;25(26):3689-3698.

138.Maulik N. Redox signaling of angiogenesis. Antioxid Redox Signal. 2002;4(5):805-815

139.Miller TW, Isenberg JS, Roberts DD. Molecular regulation of tumor angiogenesis and perfusion via redox signaling. Chem Rev. 2009;109(7):3099-3124.

140.Ushio-Fukai M. Redox signaling in angiogenesis: role of NADPH oxidase. Cardiovasc Res. 2006;71(2):226-235.

141.Matsuda M, Shimomura I. Increased oxidative stress in obesity: implications for metabolic syndrome, diabetes, hypertension, dyslipidemia, atherosclerosis, and cancer. Obes Res Clin Pract. 2013;7(5):e330-341.

142.Ross SA, Dwyer J, Umar A, Kagan J, Verma M, Van Bemmel DM, et al. Introduction: diet, epigenetic events and cancer prevention. Nutr Rev. 2008;66 Suppl1:S1-6

143.Xue J, Ideraabdullah FY. An assessment of molecular pathways of obesity susceptible to nutrient, toxicant and genetically induced epigenetic perturbation. J Nutr Biochem. 2016;30:1-13.

144.Jaenisch R, Bird A. Epigenetic regulation of gene expression: how the genome integrates intrinsic and environmental signals. Nat Genet. 2003;33Suppl:245-254.

145.Sun X, Casbas-Hernandez P, Bigelow C, Makowski L, Joseph Jerry D, Smith Schneider S, et al. Normal breast tissue of obese women is 
enriched for macrophage markers and macrophage-associated gene expression. Breast Cancer Res Treat. 2012;131(3):1003-1012.

146.Suga K, Imai K, Eguchi H, Hayashi S, Higashi Y, Nakachi K. Molecular significance of excess body weight in postmenopausal breast cancer patients, in relation to expression of insulin-like growth factor I receptor and insulin-like growth factor II genes. Jpn J Cancer Res. 2001;92(2):127-134.

147.Hair BY, Troester MA, Edmiston SN, Parrish EA, Robinson WR, Wu MC, et al. Body mass index is associated with gene methylation in estrogen receptor-positive breast tumors. Cancer Epidemiol Biomarkers Prev. 2015;24(3):580-586.

148.Dick KJ, Nelson CP, Tsaprouni L, Sandling JK, Aissi D, Wahl S, et al. DNA methylation and body-mass index: a genome-wide analysis. Lancet 2014;383:1990-1998. 